Article

\title{
Efficient Biodiesel Production Catalyzed by Nanobioconjugate of Lipase from Pseudomonas fluorescens
}

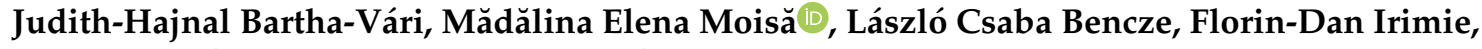 \\ Csaba Paizs $(\mathbb{D})$ and Monica Ioana Toșa *(D) \\ Babeș-Bolyai University, Biocatalysis and Biotransformation Research Center, Arany János 11, \\ 400028 Cluj-Napoca, Romania; varihajni@chem.ubbcluj.ro (J.-H.B.-V.); mmoisa@chem.ubbcluj.ro (M.E.M.); \\ cslbencze@chem.ubbcluj.ro (L.C.B.); irimie@chem.ubbcluj.ro (F.-D.I.); paizs@chem.ubbcluj.ro (C.P.) \\ * Correspondence: mtosa@chem.ubbcluj.ro; Tel.: +40-264-593833
}

Academic Editors: Simona M. Coman and Madalina Tudorache

Received: 30 December 2019; Accepted: 1 February 2020; Published: 3 February 2020

\begin{abstract}
The Amano lipase from Pseudomonas fluorescens (L-AK) was covalently immobilized on various carbon nanomaterials (functionalized single-walled carbon nanotubes and graphene oxide) and tested for biodiesel production. Using the most active lipase preparation (covalently immobilized $\mathrm{L}-\mathrm{AK}$ on $\mathrm{SwCNT}_{\mathrm{NH} 2}$ derivatized with glycerol diglycidyl ether) under optimal conditions, quasi-complete conversion (>99\%) of sunflower oil was obtained after only $4 \mathrm{~h}$ reaction time. Moreover, the biocatalyst maintained more than $99 \%$ of its initial activity in the batch system after multiple recycling experiments.
\end{abstract}

Keywords: lipase from Pseudomonas fluorescens; single-walled carbon nanotubes; biodiesel production

\section{Introduction}

According to the current consumption, the supply for the most commonly used fossil fuels will last no longer than 50 years [1]. Moreover, the use of these fuels continuously arises pollution and global warming-related problems due to the emitted greenhouse gases. Biodiesel, a mixture of fatty acid alkyl esters, can be an ecofriendly alternative to fossil fuels since it can be obtained from vegetable oils or animal fat. Biodiesel is also biodegradable; it has low toxicity and minimal emissions of sulfates and aromatic compounds [2]. The major feedstock for biodiesel production represents rapeseed oil, followed by soybean and palm oil [3], but also non-edible oils [4], used cooking oils [5], algae [6,7] or fungi oils can also be processed through transesterification with short-chain alcohols for biodiesel production. The most commonly used alcohols for the transesterification reaction are methanol and ethanol. Despite the lower costs of methanol, ethanol remained more preferred due to its low toxicity, biodegradability and the possibility to obtain it through fermentation of renewable resources [8].

Chemical processes using alkali or basic catalysts [9] at high conversion rates of the triglycerides into methyl esters present several drawbacks, including the difficulty of the catalyst removal, the glycerol recovery or the subsequent alkaline/acidic water treatment [10]. Lipase-catalyzed routes represent an environmentally friendly and cleaner alternative having as advantage a smaller number of operational steps [11]. Lipase-catalyzed transesterification processes for biodiesel synthesis using different lipases (lipases from Candida antarctica, Chromobacterium viscosum, Mucor miehei, Pseudomonas cepacia, Pseudomonas fluorescens, Porcine pancreatic, Rhizomucor miehei or Thermomyces lanuginosus) have been described [12-14]. Generally, lipases are inactivated by frequently used short-chain alcohols, such as ethanol or methanol. However, it was demonstrated that Amano lipase from Pseudomonas fluorescens has high tolerance toward ethanol and methanol, which makes it suitable 
for triglycerides transesterification [15,16]. It is also known that free enzymes have a fragile active structure and difficulties concerning their separation and reuse hamper their application in industrial processes [17]. The immobilization of enzymes, resulting in reusable biocatalysts with long-term stability [18-20] can overcome these drawbacks. Several immobilization methods have been employed for lipases used for biodiesel synthesis, such as physical adsorption, covalent attachment, entrapment or the use of cross-linked enzyme aggregates [21-23].

Covalent immobilization techniques prevent the gradual leak of the enzyme from support, increasing the recyclability and operational stability of the biocatalyst; however, the conformational flexibility of the enzyme, hence the activity, might be affected. Several materials, such as silica, ceramics, polymer resins and magnetic nanoparticles are used as support material for lipase immobilization [24-26]. Carbon nanotubes are gaining attention as support material for the immobilization of biomacromolecules, exploiting their electrical, mechanical and thermal properties, and general biocompatibility $[27,28]$. Moreover, they have the advantage to be strongly hydrophobic, thus keeping the formed glycerol away from the catalytic site of the enzymes. Graphene oxide (GO) displays two accessible sides, thus presents a larger $\left(2630 \mathrm{~m}^{2} \mathrm{~g}^{-1}\right)$ specific surface area compared to carbon nanotubes $\left(1315 \mathrm{~m}^{2} \mathrm{~g}^{-1}\right)$ [29]. Moreover, GO with a high abundance of oxygen-containing surface functionalities (such as epoxide, hydroxyl and carboxylic groups) provides ideal support material for enzyme immobilization $[29,30]$.

Immobilization may also enable the efficient production of biodiesel at an industrial level. There is a great interest in process intensification technologies, which may overcome the major drawbacks of the transesterification reactions [31]; however, due to the technical aspects of enzyme-catalyzed biodiesel synthesis, the development of suitable enzymatic reactors [32] comes up against difficulties. Currently, among the different reactors developed for biodiesel production, the most commonly used are the batch-stirred tank reactor and the packed bed reactor.

Although several studies reported high conversion in fatty acid methyl esters (FAMEs)-type biodiesel (over 90\% conversion after $30 \mathrm{~h}$ with immobilized Burkholderia sp. lipase [33]), 97\% conversion after $16 \mathrm{~h}$ using lipase from Pacific white shrimp [34] and 94\% conversion after $10 \mathrm{~h}$ with Rhizomucor miehei lipase (RML) covalently immobilized on polyamidoamine dendrimer-coated magnetic multi-walled carbon nanotubes [35]. According to our knowledge, lipase-catalyzed quasi-complete conversion of triglycerides into fatty acid ethyl esters (FAEE) has not yet been reported.

Since lipase B from Candida antarctica covalently immobilized on carboxylated single-walled carbon nanotubes ( $\mathrm{SwCNT}_{\mathrm{COOH}}$ ) proved to be a highly efficient biocatalyst for biodiesel synthesis [36], and Amano lipase from Pseudomonas fluorescens (L-AK) shows an unusually high methanol and ethanol resistance, being efficient in biodiesel production [37] even after its immobilization on hydrophobic supports by adsorption [38], the present study aims to develop a novel, highly active and stable biocatalyst for the conversion of sunflower oil into the corresponding FAEE through the covalent immobilization of L-AK on various hydrophobic carbon nanomaterial supports (carboxy and amino-functionalized single-walled carbon nanotubes ( $\mathrm{SwCNT}_{\mathrm{COOH}}$ and $\mathrm{SwCNT}_{\mathrm{NH} 2}$ ), and reduced graphene oxide $(\mathrm{rGO})$ ) of large surface area, derivatized with various linkers with different lengths.

\section{Results}

\subsection{Covalent Immobilization of $L-A K$ on Nanomaterials}

The immobilization of the lipase through covalent binding on nanomaterials was performed by similar approaches (Scheme 1) based on the protocol previously developed by us [35]. The nanosupport (SwCNT $\mathrm{COOH}$ or $\mathrm{rGO}$ ) was activated with $N, N^{\prime}$-carbonyldiimidazole (CDI, Scheme 1 , step $i$ ), to the CDI-activated support 1,3-propanediamine (Scheme 1, step ii) and then glycerol diglycidyl ether (GDE) as crosslinker (Scheme 1, step iii) were gradually bonded. The enzyme L-AK was finally reacted with the bisepoxide-activated support (Scheme 1, step iv), resulting in two biocatalysts, SwCNT $\mathrm{COOH}$-GDE-L-AK and rGO-GDE-L-AK. 

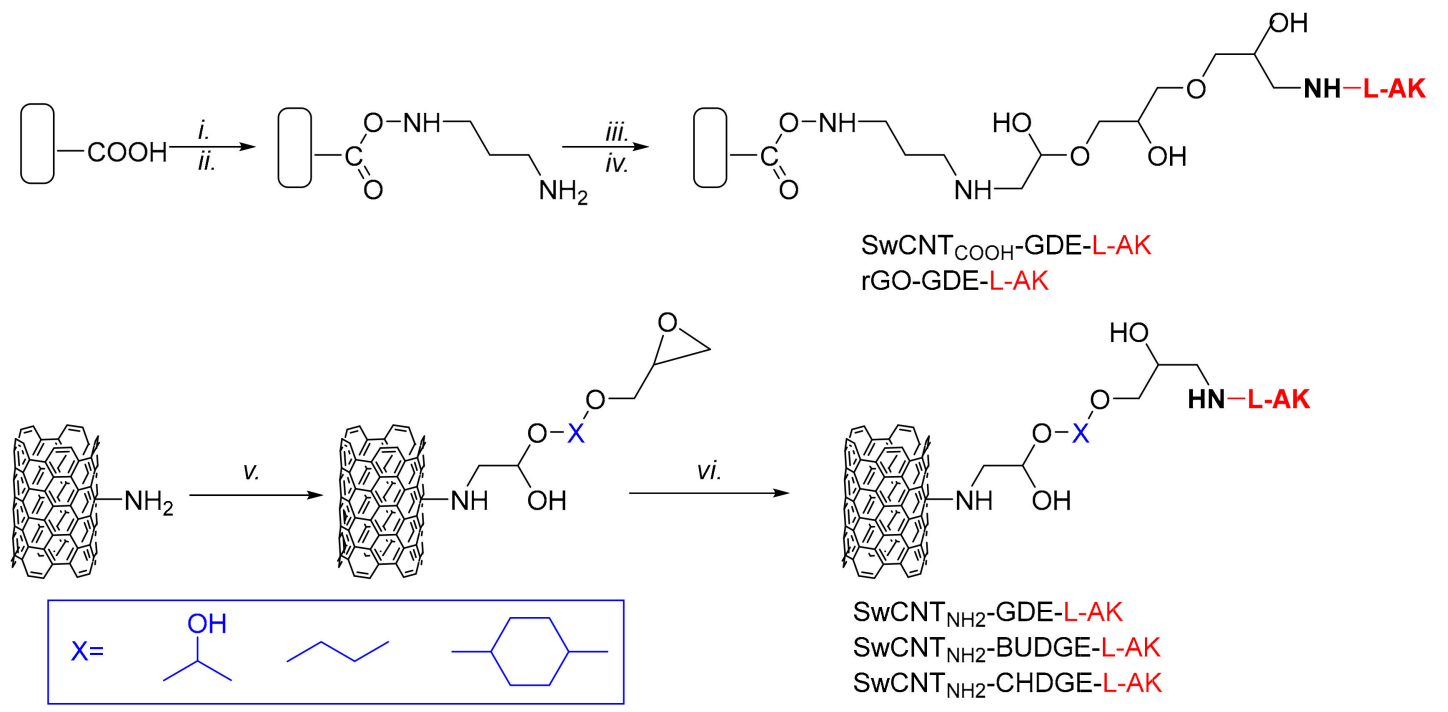

Scheme 1. Immobilization of Pseudomonas fluorescens (L-AK) on nanosupports: (i) $\mathrm{CDI}$ in $\mathrm{CH}_{2} \mathrm{Cl}_{2}$; (ii) $\mathrm{H}_{2} \mathrm{~N}-\left(\mathrm{CH}_{2}\right)_{3}-\mathrm{NH}_{2}$ in water; (iii) glycerol diglycidyl ether (GDE) in $\mathrm{CH}_{2} \mathrm{Cl}_{2}$; (iv) L-AK in PBS buffer (20 $\mathrm{mM} \mathrm{Na}_{2} \mathrm{HPO}_{4}, 150 \mathrm{mM} \mathrm{NaCl}, \mathrm{pH}$ 7); v) diglycidyl ether in $\mathrm{CH}_{2} \mathrm{Cl}_{2}$; (vi) L-AK in PBS buffer (20 mM $\mathrm{Na}_{2} \mathrm{HPO}_{4}, 150 \mathrm{mM} \mathrm{NaCl}, \mathrm{pH}$ 7).

Activated $\mathrm{SwCNT}_{\mathrm{NH} 2}$ was obtained in a single step (Scheme 1, step $v$ ) from $\mathrm{SwCNT}_{\mathrm{NH} 2}$ and GDE and further used for the enzyme covalent attachment using the free amino groups of L-AK, resulting in the desired $\mathrm{SwCNT}_{\mathrm{NH} 2}$-GDE-L-AK, as presented in Scheme 1.

Both immobilization protocols provided high immobilization yields ( $>99 \%$ of the lipase bound to the support) and were carried out in presence of the non-ionic surfactant Tween 80, known for its benefic influence upon the fixation of the enzyme in a more active open conformation, enhancing the activity of the formed biocatalyst [39].

\subsection{Transesterification Reactions Mediated by Immobilized L-AK}

Further, the catalytic properties of the immobilized enzyme preparates were tested in the transesterification of sunflower oil with ethanol. The reaction conditions were optimized in order to achieve the highest conversion rate, focusing on the effect of the nature of organic solvents, water content of the reaction mixture, substrate:nucleophile ratio and the enzyme load. For the preliminary experiments, three biocatalysts, $\mathrm{SwCNT}_{\mathrm{COOH}}-\mathrm{GDE}-\mathrm{L}-\mathrm{AK}, \mathrm{SwCNT}_{\mathrm{NH}}$-GDE-L-AK and rGO-GDE-L-AK, with an enzyme load of $0.33 \mathrm{mg}$ enzyme/mg immobilized preparation were used as model biocatalysts.

\subsubsection{The Effect of Organic Solvents upon Biodiesel Production}

The enzymatic ethanolysis of the sunflower oil was performed with all enzyme preparates in various solvents at the same enzyme:substrate ratio, identic substrate and ethanol concentrations, all at $30{ }^{\circ} \mathrm{C}$. Samples were taken after $4 \mathrm{~h}$ reaction time and the process was monitored with ${ }^{1} \mathrm{H}-\mathrm{NMR}$ spectrometry. While in dichloromethane the biocatalysts were almost inactive, in tert-butanol and in tert-butylmethylether ( $t$-BME), the L-AK preparates displayed moderate activities. Since in $n$-hexane, neat ethanol and acetonitrile the enzymatic transesterification reactions underwent good conversions, iso-octane was selected as the best solvent, allowing the maximal transformation after $4 \mathrm{~h}$ with two biocatalysts. While $\mathrm{SwCNT}_{\mathrm{COOH}}$ and $\mathrm{SwCNT}_{\mathrm{NH} 2}$ were appropriate carriers for $\mathrm{L}-\mathrm{AK}$ covalent binding (c $>90 \%$ in iso-octane), L-AK immobilized on rGO displayed unfortunately reduced enzyme activity (c $>58 \%$ in iso-octane) for biodiesel production (Figure 1). As a consequence, this biocatalyst was not included in further experiments. 


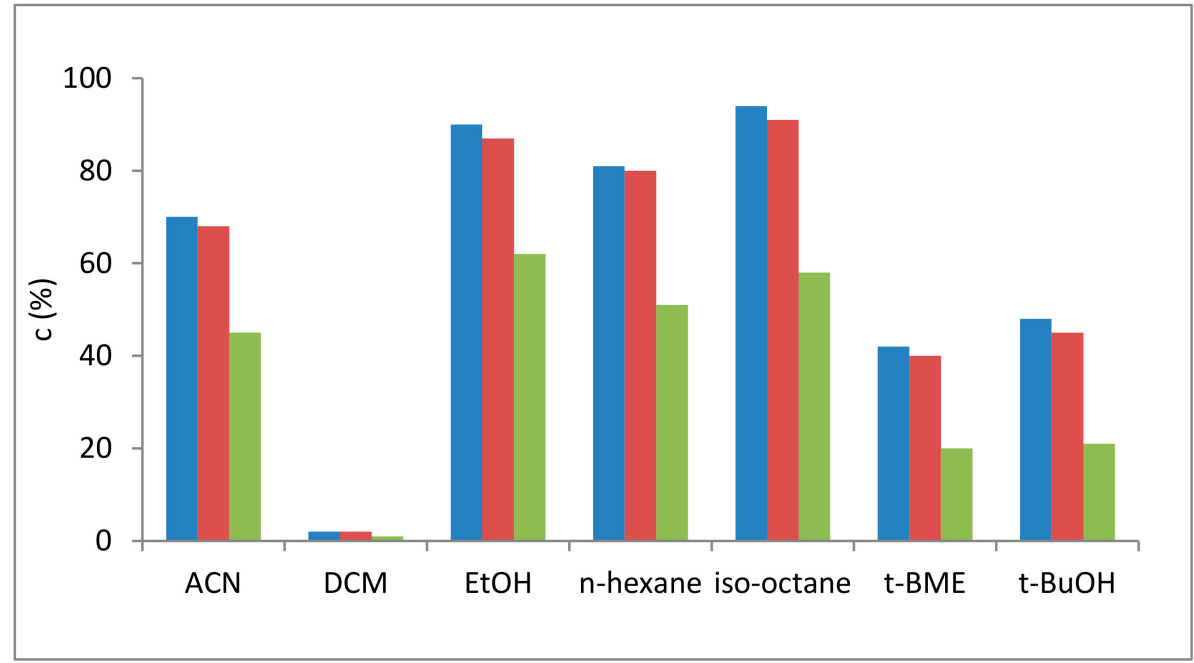

Figure 1. The influence of the solvent on the ethanolysis of sunflower oil catalyzed by single-walled carbon nanotubes $(\mathrm{SwCNT})_{\mathrm{NH} 2}$-GDE-L-AK (blue bars), SwCNT $\mathrm{COOH}$-GDE-L-AK (red bars) and reduced graphene oxide (rGO)-GDE-L-AK (green bars) $(4 \mathrm{~h})$.

\subsubsection{The Effect of Water Content on Biodiesel Production}

The activity and selectivity of lipases are strongly influenced by the water content of the reaction mixture. The presence of a certain minimal amount of water is crucial to maintain the conformational mobility of the protein, with direct influence upon the efficacy of the lipase preparate. However, in the case of the alcoholysis of tryglicerides in various organic solvents, the influence of the water content upon the efficacy of various lipases is fuzzy. While the synthesis of fatty acid alkyl esters mediated by Candida antarctica lipase B (CALB) is negatively influenced by the increasing of the water content of the reaction mixture [40], the efficacy of lipases from other Candida species, from Rhizopus oryzae and from Pseudomonas cepacia increased with water content of the reaction mixture [41,42].

In this context, the influence of the water content $(0-5 \%, v / v)$ of the reaction mixture upon the SwCNT $\mathrm{COOH}$-GDE-L-AK and $\mathrm{SwCNT}_{\mathrm{NH} 2}$-GDE-L-AK catalyzed ethanolysis of sunflower oil was next investigated (Figure 2). Increasing the water concentration from 0.1 to $2 \% v / v$, a linear drastic decrease of the conversion into biodiesel was observed. Interestingly, further increase of the water concentration gradually enhanced the enzyme activity with a local maximum at $4 \% v / v$ water content.

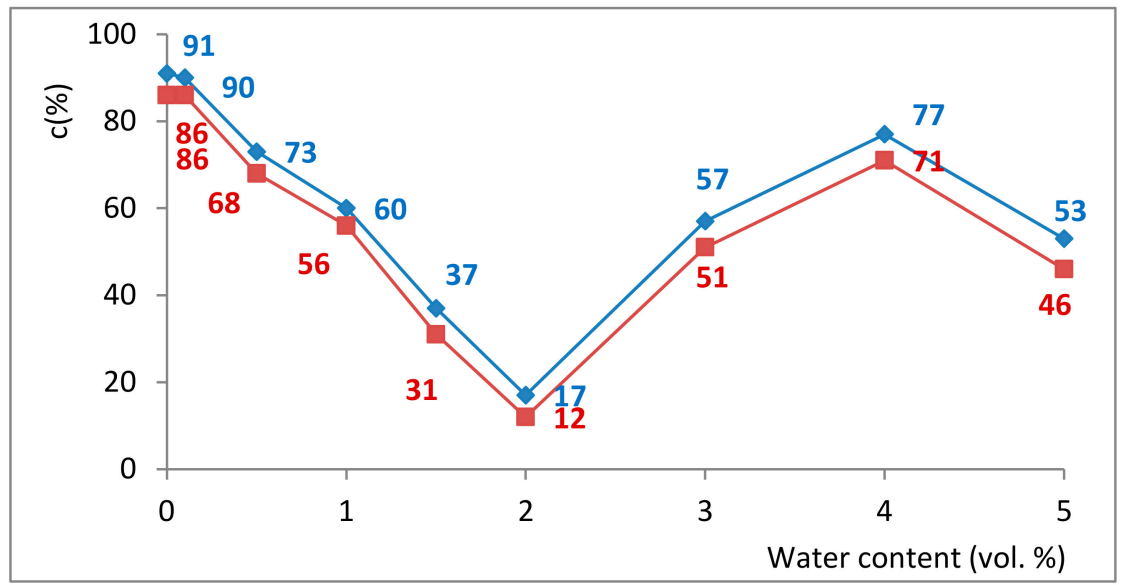

Figure 2. The effect of water content on the biodiesel production with $\mathrm{SwCNT}_{\mathrm{COOH}}-\mathrm{GDE}-\mathrm{L}-\mathrm{AK}$ (red points) and $\mathrm{SwCNT}_{\mathrm{NH} 2}$-GDE-L-AK (blue points) in iso-octane $(4 \mathrm{~h})$. 
Probably, in the presence of water, the hydrolysis reaction competes with biodiesel formation, and as shown in Figure 2, the highest enzyme activity was achieved in the absence of water.

2.2.3. The Influence of the Protein Content of the Biocatalysts upon the Specific Enzyme Activity for the Transesterification Reactions

Besides the used immobilization method and the nature of the support, the catalytic performance of the biocatalyst could also be influenced by the enzyme load of the biocatalyst. The large surface area and the presence of $\sim 3-5 \% w / w$ content of the active carboxy or amino functional groups of the tested $\mathrm{SwCNT}_{\mathrm{COOH}}$ and $\mathrm{SwCNT}_{\mathrm{NH} 2}$ carbon nanomaterials enabled the covalent binding of even $4 \mathrm{mg}$ protein/1 mg support, [43] which could lead to the partial inactivation of enzymes caused by the steric hindrance of the protein molecules. Since, until this stage, preparates with an enzyme load of $0.33 \mathrm{mg}$ $\mathrm{L}-\mathrm{AK} / \mathrm{mg}$ biocatalyst were used, the ethanolysis of sunflower oil was further tested in the presence of biocatalysts with various protein content (Figure 3$)$. The highest activity ( $\sim 93 \%$ conversion after $3 \mathrm{~h}$ ) was obtained for the biocatalyst containing around 66\% L-AK (corresponding to a support:enzyme ratio of $1: 2, w / w)$.

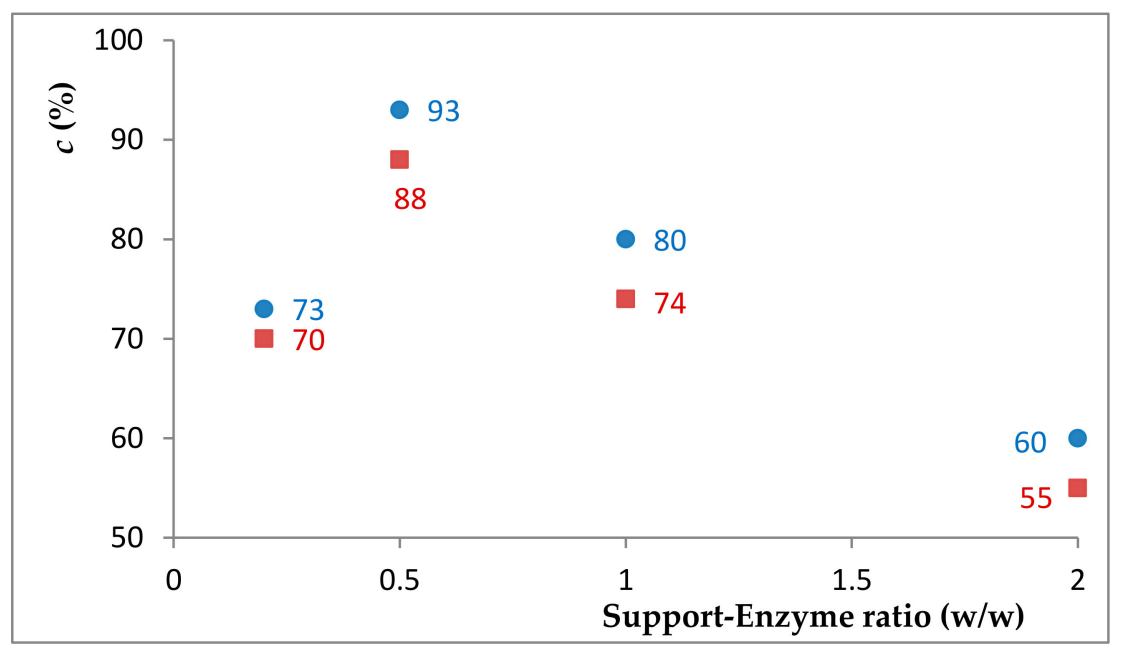

Figure 3. The effect of the enzyme load on the conversion of the transesterification reaction $(3 \mathrm{~h})$ with SwCNT $\mathrm{COOH}_{-}-\mathrm{GDE}-\mathrm{L}-\mathrm{AK}$ (red points) and $\mathrm{SwCNT}_{\mathrm{NH} 2}$-GDE-L-AK (blue points).

\subsubsection{The Effect of the Oil-Ethanol Molar Ratio}

Since the amount of nucleophile can significantly influence the reaction rate of the biocatalytic transesterification processes, the biocatalyst's activity at various oil:ethanol ratios was tested (Table 1). Using low, stoichiometric ethanol content, including the 1:5 oil:ethanol ratio of the previous experiments, the activity of both biocatalysts was high, achieving maximal conversions (97-98\% conversion in $3 \mathrm{~h}$, Table 1, Entry 5) at a 1:7 oil:ethanol molar ratio. Higher ethanol content caused the continuous decrease of the conversions probably due to the presence of insoluble alcohol droplets in oil that caused denaturation of the enzyme, as already reported for enzymatic methanolysis of oils [44]. 
Table 1. The effect of oil:ethanol molar ratio on the ethanolysis process catalyzed by SwCNT immobilized L-AK (3 h reaction time).

\begin{tabular}{|c|c|c|c|}
\hline \multirow{2}{*}{ Entry } & \multirow{2}{*}{ Oil:Ethanol Molar Ratio } & \multicolumn{2}{|c|}{ Conversion $(\%)$} \\
\hline & & SwCNT $_{\mathrm{COOH}^{-G D E}-\mathrm{L}-\mathrm{AK}}$ & SwCNT $_{\mathrm{NH} 2}$-GDE-L-AK \\
\hline 1 & $1: 1$ & 67.1 & 68.8 \\
\hline 2 & $1: 3$ & 93.1 & 94.2 \\
\hline 3 & $1: 5$ & 96.1 & 96.8 \\
\hline 4 & $1: 6$ & 96.8 & 97.4 \\
\hline 5 & 1:7 & 97.1 & 98.0 \\
\hline 6 & $1: 8$ & 94.1 & 95.2 \\
\hline 7 & $1: 10$ & 93.7 & 94.5 \\
\hline 8 & $1: 20$ & 94.9 & 95.2 \\
\hline 9 & $1: 50$ & 67.1 & 68.9 \\
\hline
\end{tabular}

\subsubsection{Reusability of the Immobilized Lipases}

As demonstrated recently by Hessel [45], a major cost for the scaled-up production of biodiesel in a continuous flow reactor is related to the enzyme costs influenced by the support material itself. However, when the immobilization yield and the biocatalyst stability are high, the enzymatic process is in general economically viable, sustainable and environmentally friendly, as compared with the chemical classic routes.

The covalently attached lipase on the support material should be suitable for long-term use since the leakage of the enzyme from the nanotubes is disabled. Further, the reusability of SwCNT $\mathrm{COOH}$-GDE-L-AK and $\mathrm{SwCNT}_{\mathrm{NH} 2}$-GDE-L-AK (0.66 mg L-AK/mg preparate) was tested in repeated batch cycles (Figure 4).

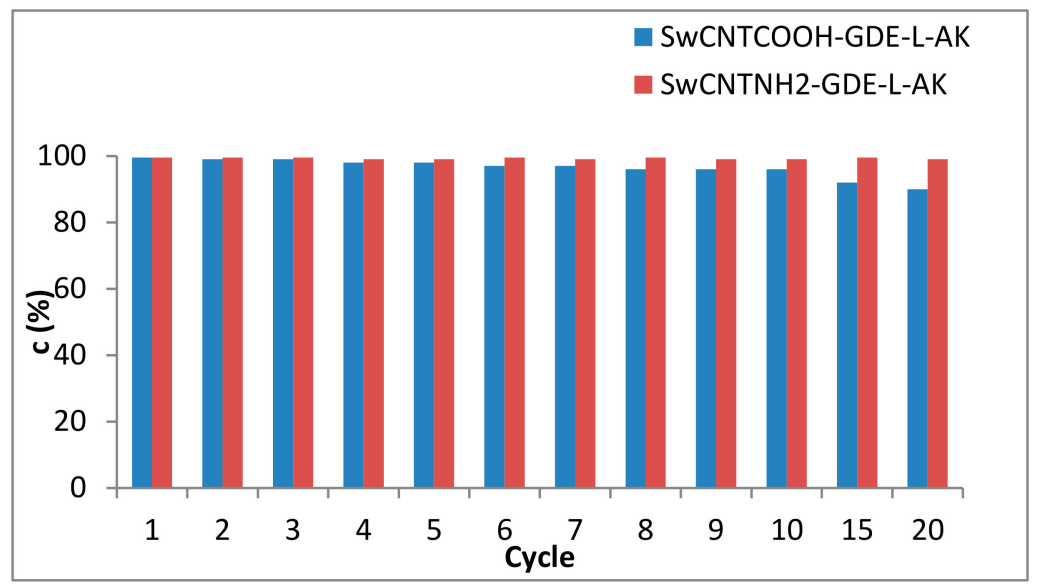

Figure 4. The time profile of the SwCNT $\mathrm{NH}_{2}$-GDE-L-AK (red bars) and $\mathrm{SwCNT}_{\mathrm{COOH}}$-GDE-L-AK (blue bars) mediated transesterification of sunflower oil after $4 \mathrm{~h}$ (dry iso-octane, oil-ethanol 1:5 molar ratio).

Both enzyme preparates presented high activity. While for $\mathrm{SwCNT}_{\mathrm{COOH}}-\mathrm{GDE}-\mathrm{L}-\mathrm{AK}$, a small and gradual inactivation was measured, the near-complete transformation of the sunflower oil ( $>99 \%$ conversion) was observed even after 20 reaction cycles when $\mathrm{SwCNT}_{\mathrm{NH}_{2}}$-GDE-L-AK was used, this preparate providing an excellent operational stability since only a small activity decrease (approx. $0.5 \%)$ was detected even after 20 reaction cycles.

\subsubsection{Other Linkers for Enzyme Immobilization on $\mathrm{SwCNT}_{\mathrm{NH} 2}$}

Finally, in our attempt to increase the activity of the lipase preparation, besides GDE, other cross-linkers with different lengths and structures were used as spacer arms for the L-AK covalent immobilization on $\mathrm{SwCNT}_{\mathrm{NH} 2}$. For this scope, 1,4-butanediol diglycidyl ether and 
1,4-cyclohexanedimethanol diglycidyl ether were used for immobilization (Scheme 1) and the newly

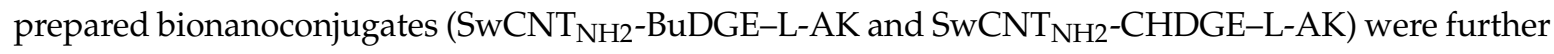
tested in the previously found optimal conditions for oil ethanolysis in several cycles.

The conversions obtained using the $\mathrm{SwCNT}_{\mathrm{NH} 2}$-CHDGE-L-AK with the more rigid cyclohexanetype linker, or the $\mathrm{SwCNT}_{\mathrm{NH} 2}$-BuDGE-L-AK with a more mobile but hydrophobic butyl spacer arm were moderate compared to those obtained with $\mathrm{SwCNT}_{\mathrm{NH} 2}$-GDE-L-AK (Figure 5). Moreover,

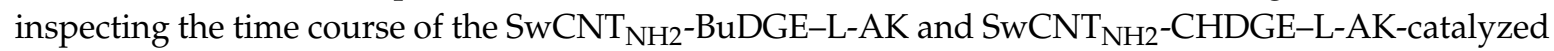
reactions, in both cases, the productivities are unsatisfactory, with only $\sim 60 \%$ maximal conversion of oil into the desired FAEE being observed.

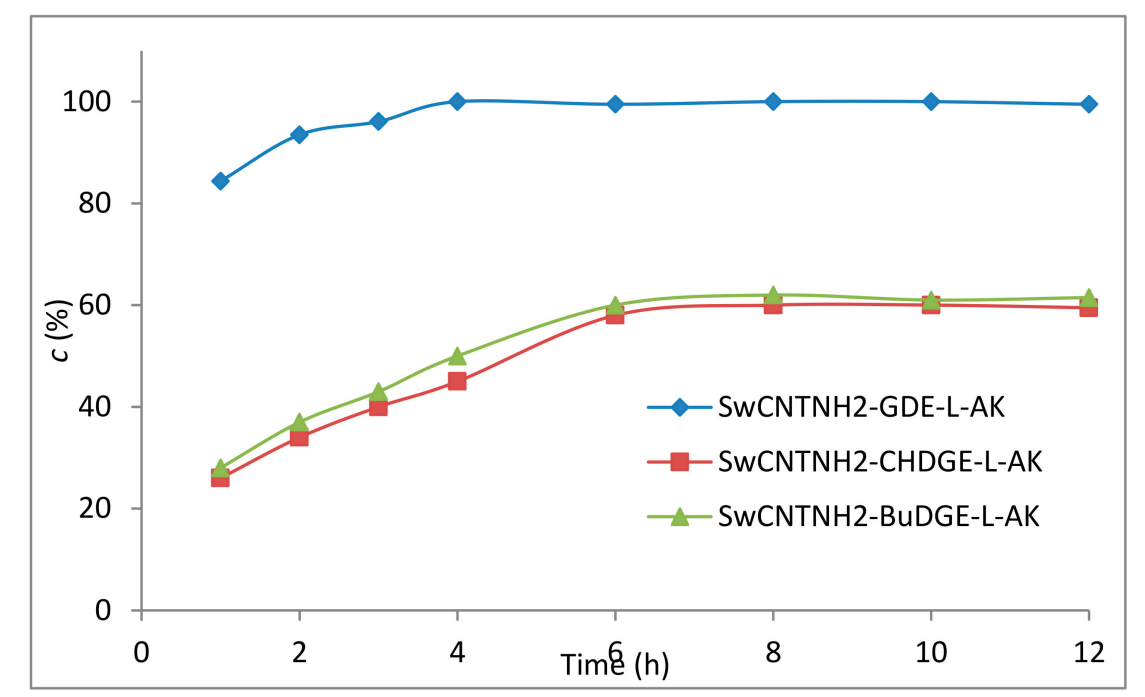

Figure 5. The time profile of the immobilized L-AK-mediated transesterification of sunflower oil.

\section{Materials and Methods}

\subsection{Materials}

Native Amano lipase from Pseudomonas fluorescens (L-AK) was purchased as lyophilized powder from Chiral Vision, Netherlands. Graphene, single-walled carbon nanotubes (SwCNT; ID = 0.8-1.6 nm, OD 1-2 nm, length $=5-30 \mu \mathrm{m})$ and carboxylated single-walled carbon nanotubes $\left(\mathrm{SwCNT}_{\mathrm{COOH}}\right)(\mathrm{COOH}$ content: $2.73 \mathrm{wt} \%$; ID $=0.8-1.6 \mathrm{~nm}, \mathrm{OD}=1-2 \mathrm{~nm}$, length $=5-33 \mu \mathrm{m}$ ) were purchased from Chengdu Organic Chemicals Co. Ltd., China. N,N'-Carbonyldiimidazole and 1,3-propanediamine were products of Alfa Aesar (Ward Hill, MA, USA). Glycerol diglycidyl ether (GDE), 1,4-butanediol diglycidyl ether, 1,4-cyclohexanedimethanol diglycidyl ether, Bradford reagent for protein determination, Tween-80 and $\mathrm{CDCl}_{3}$ were purchased from Sigma-Aldrich (St. Luis, MO, USA). The sunflower oil was obtained from a local store. All solvents, technical grade, were dried and/or freshly distilled prior to use.

\subsection{Equipments}

For the Bradford protein assay, an Agilent 8453 UV-Vis spectrophotometer was used. During enzyme immobilization, ultrasonications were performed in a Transsonic 460/H ultrasonic bath, Elma Schmidbauer $\mathrm{GmbH}$, at $100 \mathrm{~W}$ and $40 \mathrm{kHz}$.

The shaking and incubation of enzymatic reactions were performed using a Titramax 1000 instrument, equipped with a heating module. ${ }^{1} \mathrm{H}-\mathrm{NMR}$ spectra were recorded in $\mathrm{CDCl}_{3}$ as solvent at $25{ }^{\circ} \mathrm{C}$ on Bruker Avance 400 and Bruker Avance 600 NMR spectrometers, operating at 400 and $600 \mathrm{MHz}$, respectively. The ${ }^{1} \mathrm{H}-\mathrm{NMR}$ spectral parameters were: spectral width $12,019.2 \mathrm{~Hz}$, acquisition time $2.99 \mathrm{~s}$ and number of scans 32 . Signals were expressed in ppm on the $\delta$ scale. 
GC analysis was performed on an Agilent 7890A GC gas chromatograph equipped with a flame ionization detector on a DB-WAX capillary column $(30 \mathrm{~m} \times 0.32 \mathrm{~mm} \times 0.5 \mu \mathrm{m})$.

Elemental analyses were carried out with a Vario Micro Cube analyzer, Elementer Analysen Systeme GmBH (Langeselbold, Germany).

The amination reaction was carried out at $600 \mathrm{~W}$ power at 50 bar pressure at $300{ }^{\circ} \mathrm{C}$ for $1 \mathrm{~h}$ in a CEM microwave-assisted reactor (CEM Corporation (Matthews, NC, USA)).

All mixtures containing SwCNTs were filtered on a PTFE membrane filter with $0.22 \mu \mathrm{m}$ pore size, Membrane-solutions, Nantong Co., Ltd. (Shanghai, China).

\subsection{Methods}

\subsubsection{Determination of Conversion}

The conversions of the transesterification reactions were determined as earlier described [35] recording the ${ }^{1} \mathrm{H}-\mathrm{NMR}$ spectra of the reaction mixtures. Reference spectra of the authentic biodiesel, sunflower oil and their mixtures were used for calibration (see Supplementary Materials).

\subsubsection{Functionalization of SwCNT with Amino Groups}

The functionalization of carbon nanotubes was carried out as earlier described [46]. SwCNT $(400 \mathrm{mg}$ ) and urea $(400 \mathrm{mg}$ ) were suspended in dimethyl formamide (DMF, $5 \mathrm{~mL}$ ). The reaction was carried out in a microwave-assisted reactor at $300^{\circ} \mathrm{C}$ for $1 \mathrm{~h}$. The functionalized SwCNT was washed with DMF, methanol, $\mathrm{CH}_{2} \mathrm{Cl}_{2}$ and dried. The obtained aminated support $\mathrm{SwCNT}_{\mathrm{NH} 2}$ contained $\sim 4.8 \%$ $\mathrm{NH}_{2}$ (determined by elemental analysis).

\subsubsection{Fatty Acid Composition of Sunflower Oil}

The fatty acid composition of the sunflower oil was determined according to the AOAC reference procedure as earlier reported using chromatographically pure methyl ester standards [35] (see Supplementary Materials, Figure S1).

\subsubsection{Covalent Binding of L-AK to SwCNT $\mathrm{COOH}$}

Lipase immobilization on carboxylated single-walled carbon nanotubes $\mathrm{SwCNT}_{\mathrm{COOH}}$ was achieved as previously described (Scheme 1) [35]. In all cases, high immobilization yields characterized the resulted products ( $>99 \%$ of the enzyme bound to the support; enzyme load: $0.33 / 0.5 / 0.66 / 0.83 \mathrm{mg}$ protein/mg immobilized preparation).

\subsubsection{Covalent Binding of L-AK to $\mathrm{SwCNT}_{\mathrm{NH} 2}$}

$\mathrm{SwCNT}_{\mathrm{NH} 2}(20 \mathrm{mg})$ was incubated with a solution of diglycidyl ether (glycerol diglycidyl ether, 1,4-butanediol diglycidyl ether or 1,4-cyclohexanedimethanol diglycidyl ether, $0.2 \mathrm{mmol}$ ) in $\mathrm{CH}_{2} \mathrm{Cl}_{2}$ $(5 \mathrm{~mL})$ under shaking (at $1350 \mathrm{rpm}$ ) at room temperature overnight, with occasional sonication to avoid bundled SwCNT formation (Scheme 1, step $v$ ). The mixture was filtered on a membrane filter and then washed with $\mathrm{CH}_{2} \mathrm{Cl}_{2}(3 \times 1 \mathrm{~mL})$. In the solution of L-AK $(40 \mathrm{mg})$ and Tween-80 $(6.5 \mu \mathrm{L})$ in $6 \mathrm{~mL}$ PBS buffer $\left(20 \mathrm{mM} \mathrm{Na}_{2} \mathrm{HPO}_{4}, 150 \mathrm{mM} \mathrm{NaCl}, \mathrm{pH} 7,6 \mathrm{~mL}\right)$, the bisepoxide-activated $\mathrm{SwCNT}_{\mathrm{NH} 2}(20 \mathrm{mg})$ was added and the mixture was shaken at room temperature at $1350 \mathrm{rpm}$ overnight (Scheme 1, step vi). The resulted biocatalyst (SwCNT $\mathrm{NH}_{2}-\mathrm{GDE}-\mathrm{L}-\mathrm{AK}, \mathrm{SwCNT}_{\mathrm{NH} 2}-\mathrm{BuDGE}-\mathrm{L}-\mathrm{AK}$, $\mathrm{SwCNT}_{\mathrm{NH} 2}$-CHDGE-L-AK) was filtered off on a membrane filter, sonicated several times and washed with water $(3 \times 10 \mathrm{~mL})$ until no protein trace was detected in the filtrate. After that, immobilized enzymes were freeze-dried and used in enzymatic tests. The amount of the immobilized L-AK on the bisepoxide-activated $\mathrm{SwCNT}_{\mathrm{NH} 2}$ was determined as the difference between the total mass of the enzyme in the solution before immobilization and in the unified filtrates after immobilization. In all cases, high immobilization yields characterized the resulted products ( $>99 \%$ of the enzyme bound to 
the support; enzyme loading: $0.66 \mathrm{mg}$ protein/mg immobilized preparation). For different enzyme loading, the corresponding L-AK quantities were used.

\subsubsection{Covalent Binding of L-AK to Reduced Graphene Oxide (rGO)}

Reduced graphene oxide (rGO, $20 \mathrm{mg}$ ) was activated with $N, N^{\prime}$-carbonyldiimidazole (CDI, $32.4 \mathrm{mg}, 0.2 \mathrm{mmol}$ ) in $\mathrm{CH}_{2} \mathrm{Cl}_{2}$ (5 mL) under shaking (at $1350 \mathrm{rpm}$ and room temperature, overnight), with occasional sonication, to avoid bundled rGO formation. After CDI activation, the sample was filtered on a membrane filter and then washed with $\mathrm{CH}_{2} \mathrm{Cl}_{2}(3 \times 5 \mathrm{~mL})$. Into the suspension of the CDI-activated rGO $(20 \mathrm{mg})$ in distilled water $(5 \mathrm{~mL}), 1,3$-propanediamine $(0.12 \mathrm{mmol})$ was added and the reaction mixture was shaken (at $1350 \mathrm{rpm}$ and room temperature, overnight), with occasional sonication to avoid bundled nanoparticle formation. The reaction mixture was filtered on a membrane filter, washed with distilled water $(3 \times 5 \mathrm{~mL})$ and then dried. In the solution of glycerol diglycidyl ether (GDE, $100 \mu \mathrm{L})$ in $\mathrm{CH}_{2} \mathrm{Cl}_{2}(5 \mathrm{~mL})$, diamine-coupled $\mathrm{rGO}(20 \mathrm{mg})$ was suspended and the reaction mixture was shaken (at $1350 \mathrm{rpm}$ and room temperature, overnight), with occasional sonication. The mixture was filtered on a membrane filter and then washed with $\mathrm{CH}_{2} \mathrm{Cl}_{2}(3 \times 5 \mathrm{~mL})$. In the solution of L-AK $(10 \mathrm{mg})$ and Tween-80 $(6.5 \mu \mathrm{L})$ in $6 \mathrm{~mL}$ PBS buffer $\left(20 \mathrm{mM} \mathrm{Na}_{2} \mathrm{HPO}_{4}, 150 \mathrm{mM}\right.$ $\mathrm{NaCl}, \mathrm{pH} 7)$, the bisepoxide-activated $\mathrm{rGO}(20 \mathrm{mg})$ was added and the mixture was shaken at room temperature at $1350 \mathrm{rpm}$, overnight. The resulted biocatalyst (rGO - GDE-L-AK) was filtered off on a membrane filter and, sonicated several times and washed with water $(3 \times 10 \mathrm{~mL})$ until no protein trace was detected in the filtrate. After that, the immobilized enzyme was freeze-dried and used in enzymatic transesterifications. The amount of the immobilized L-AK on the bisepoxide-activated rGO was determined as the difference between the total mass of the enzyme in the solution before immobilization and in the unified filtrates after immobilization ( $>99 \%$ of the enzyme bound to the support; enzyme loading: $0.33 \mathrm{mg}$ protein/ $\mathrm{mg}$ biocatalyst).

\subsubsection{Biodiesel Production by Enzymatic Ethanolysis}

General procedure: reactions were performed using $20 \mathrm{mg}$ sunflower oil (approx. $23 \mu \mathrm{mol}$ ) in $500 \mu \mathrm{L}$ organic solvent, $3 \mathrm{mg}$ enzyme preparate and $6.5 \mu \mathrm{L}$ ethanol (approx. $110 \mu \mathrm{mol}$ ). The reaction mixtures were shaken (1350 rpm) at room temperature for 3-4 h. The mixtures were centrifuged at $9840 \times g(13,400 \mathrm{rpm})$ for $1 \mathrm{~min}$, the solvent was removed from the supernatant at reduced pressure and the obtained biodiesel was analyzed using ${ }^{1} \mathrm{H}-\mathrm{NMR}$ spectroscopy.

In order to determine the optimal solvent for the transesterification reaction, several organic solvents were tested in the general procedure (acetonitrile, dichlorometane, ethanol, $n$-hexane, iso-octane, methyl tert-butyl ether and tert-butanol). In $500 \mu \mathrm{L}$ organic solvent, $20 \mathrm{mg}$ sunflower oil, $3 \mathrm{mg}$ enzyme preparate and $6.5 \mu \mathrm{L}$ ethanol were added. The reaction mixtures were shaken $(1350 \mathrm{rpm})$ at room temperature for $4 \mathrm{~h}$. The mixtures were centrifuged at $9840 \times g(13,400 \mathrm{rpm})$ for $1 \mathrm{~min}$, the solvent was removed from the supernatant at reduced pressure and the obtained biodiesel was analyzed using ${ }^{1} \mathrm{H}-\mathrm{NMR}$ spectroscopy.

Different amounts of water were added to the iso-octane used as a solvent for the enzymatic transesterification reaction with the aim to find the optimal water content. In $500 \mu \mathrm{L}$ iso-octane (containing $0-5 \%, v / v$ water), $20 \mathrm{mg}$ sunflower oil, $3 \mathrm{mg}$ enzyme preparate and $6.5 \mu \mathrm{L}$ ethanol were added. The reaction mixtures were shaken $(1350 \mathrm{rpm})$ at room temperature for $4 \mathrm{~h}$. The mixtures were centrifuged at $9840 \times g(13,400 \mathrm{rpm})$ for $1 \mathrm{~min}$, the solvent was removed from the supernatant at reduced pressure and the obtained biodiesel was analyzed using ${ }^{1} \mathrm{H}-\mathrm{NMR}$ spectroscopy.

The effect of the enzyme load was studied using biocatalysts with different support:enzyme ratios. In $500 \mu \mathrm{L}$ iso-octane, $20 \mathrm{mg}$ sunflower oil, the corresponding amount of the enzyme preparate and $6.5 \mu \mathrm{L}$ ethanol were added. The reaction mixtures were shaken $(1350 \mathrm{rpm})$ at room temperature for $3 \mathrm{~h}$. The mixtures were centrifuged at $9840 \times g(13,400 \mathrm{rpm})$ for $1 \mathrm{~min}$, the solvent was removed from the supernatant at reduced pressure and the obtained biodiesel was analyzed using ${ }^{1} \mathrm{H}-\mathrm{NMR}$ spectroscopy. 
During the optimization of the oil:ethanol molar ratio, different oil:ethanol mixtures were used. In $500 \mu \mathrm{L}$ iso-octane, $20 \mathrm{mg}$ sunflower oil, $1.5 \mathrm{mg}$ enzyme preparate and the corresponding amount of ethanol (1:1, 1:3, 1:5, 1:6, 1:7, 1:8, 1:10, 1:20, 1:50 oil:ethanol molar ratio) were added. The reaction mixtures were shaken $(1350 \mathrm{rpm})$ at room temperature for $3 \mathrm{~h}$. The mixtures were centrifuged at $9840 \times g(13,400 \mathrm{rpm})$ for $1 \mathrm{~min}$, the solvent was removed from the supernatant at reduced pressure and the obtained biodiesel was analyzed using ${ }^{1} \mathrm{H}-\mathrm{NMR}$ spectroscopy.

Optimized procedure: The mixture of $20 \mathrm{mg}$ sunflower oil in $500 \mu \mathrm{L}$ iso-octane, $1.5 \mathrm{mg}$ biocatalyst containing $1 \mathrm{mg}$ L-AK and $6.5 \mu \mathrm{L}$ ethanol was shaken $(1350 \mathrm{rpm})$ at $30{ }^{\circ} \mathrm{C}$ for $3 \mathrm{~h}$. The mixture was centrifuged at $9840 \times g$ for $1 \mathrm{~min}(13,400 \mathrm{rpm})$, the solvent was removed from the supernatant at reduced pressure and the obtained biodiesel was analyzed using ${ }^{1} \mathrm{H}-\mathrm{NMR}$ spectroscopy.

\section{Conclusions}

In the present study, Amano lipase from Pseudomonas fluorescens (L-AK) has been covalently immobilized on functionalized single-walled carbon nanotubes and reduced graphene oxide and the obtained enzyme preparations were used for the production of biodiesel in the batch system. The most active lipase preparate was achieved when amino-functionalized carbon nanotubes as support and GDE as crosslinker ( $\left.\mathrm{SwCNT}_{\mathrm{NH} 2}-\mathrm{GDE}-\mathrm{L}-\mathrm{AK}\right)$ were used. Under the optimal conditions of the batch procedure, the novel biocatalyst provided high activity. With almost complete conversions of the sunflower oil to biodiesel in only $4 \mathrm{~h}$ and impressive stability, the activity was maintained unaltered even after 20 reaction cycles.

Supplementary Materials: The following are available online. Determination of conversion values through ${ }^{1} \mathrm{H}-\mathrm{NMR} ; 2$. Fatty acid composition of sunflower oil; 3. Biodiesel production through basic ethanolysis.

Author Contributions: All authors have read and agreed to the published version of the manuscript. Conceptualization, M.I.T. and L.C.B.; methodology, C.L.B. and C.P.; validation, F.-D.I.; analysis, M.E.M. and J.-H.B.-V.; investigation, J.-H.B.-V.; writing-original draft preparation, J.-H.B.-V. and L.C.B.; writing-review and editing, M.I.T. and C.P.; supervision, M.I.T. and C.P.; funding acquisition, F.-D.I.

Funding: This research was funded by National Authority for Scientific Research and Innovation (ANCSI) and European Regional Development Fund, Competitiveness Operational Program 2014-2020 (POC, Priority Axis 1, Action 1.1), grant NEMSyB (ID P37_273, code MySMIS 103413). The present work has received financial support through the project Entrepreneurship for Innovation through Doctoral and Postdoctoral Research, POCU/360/6/13/123886, co-financed by the European Social Fund, through the Operational Program for Human Capital 2014-2020.

Conflicts of Interest: The authors declare no conflicts of interest.

\section{References}

1. Hwang, H.T.; Qi, F.; Yuan, C.; Zhao, X.; Ramkrishna, D.; Liu, D.; Varma, A. Lipase-Catalyzed Process for Biodiesel Production: Protein Engineering and Lipase Production. Biotechnol. Bioeng. 2014, 111, 639-653. [CrossRef]

2. Atabani, A.E.; Silitonga, A.S.; Badruddin, I.A.; Mahlia, T.M.I.; Masjuki, H.H.; Mekhilef, S.A. Comprehensive Review on Biodiesel as an Alternative Energy Resource and its Characteristics. Renew. Sustain. Energy Rev. 2012, 16, 2070-2093. [CrossRef]

3. Moser, B.R. Biodiesel Production, Properties, and Feedstocks. In Vitro Cell. Dev. Biol.- Plant 2009, 45, $229-266$. [CrossRef]

4. Murugesan, A.; Umarani, C.; Chinnusamy, T.R.; Krishnan, M.; Subramanian, R.; Neduzchezhain, N. Production and Analysis of Bio-Diesel from Non-Edible Oils-A Review. Renew. Sustain. Energy Rev. 2009, 13, 825-834. [CrossRef]

5. Enweremadu, C.C.; Rutto, H.L. Combustion, Emission and Engine Performance Characteristics of Used Cooking Oil Biodiesel-A Review. Renew. Sustain. Energy Rev. 2010, 14, 2863-2873. [CrossRef]

6. Scott, S.A.; Davey, M.P.; Dennis, J.S.; Horst, I.; Howe, C.J.; Lea-Smith, D.J.; Smith, A.G. Biodiesel from Algae: Challenges and Prospects. Curr. Opin. Biotechnol. 2010, 21, 277-286. [CrossRef] [PubMed] 
7. Pacheco, M.M.; Hoeltz, M.; de Souza, D.; Benitez, L.B.; Schneider, R.C.S.; Muller, M.V.G. Current Approaches in Producing Oil and Biodiesel from Microalgal Biomass. In Waste Biomass Management - A Holistic Approach; Singh, L., Kalia, V.C., Eds.; Springer International Publishing AG: Cham, Switzerland, 2017; pp. $289-310$.

8. Akoh, C.C.; Chang, S.; Lee, G.; Shaw, J. Enzymatic Approach to Biodiesel Production. J. Agric. Food Chem. 2007, 55, 8995-9005. [CrossRef]

9. Zhang, Y. Biodiesel Production from Waste Cooking Oil: 1. Process Design and Technological Assessment. Bioresour. Technol. 2003, 89, 1-16. [CrossRef]

10. Meher, L.; Vidyasagar, D.; Naik, S. Technical Aspects of Biodiesel Production by Transesterification-A Review. Renew. Sustain. Energy Rev. 2006, 10, 248-268. [CrossRef]

11. Irimie, F.D.; Paizs, C.; Toşa, M.I.; Bencze, L.C. Biodiesel A Green Fuel Obtained through Enzymatic Catalysis. In Biomass Asrenewable Raw Material for Bioproducts; Popa, V., Volf, I., Eds.; Elsevier Press: Oxford, UK, 2018.

12. Stamenković, O.S.; Veličković, A.V.; Veljković, V.B. The Production of Biodiesel from Vegetable Oils by Ethanolysis: Current State and Perspectives. Fuel 2011, 90, 3141-3155. [CrossRef]

13. Reza, M.; Mohammadi, M.J.; Peyda, M.; Mohammadi, M. Covalent Immobilization of Candida Antarctica Lipase on Core-Shell Magnetic Nanoparticles for Production of Biodiesel from Waste Cooking Oil. Renew. Energy 2017, 101, 593-602.

14. Encinar, J.M.; González, J.F.; Sánchez, N.; Nogales-Delgado, S. Sunflower Oil Transesterification with Methanol Using Immobilized Lipase Enzymes. Bioprocess Biosyst. Eng. 2019, 42, 157-166. [CrossRef] [PubMed]

15. Salis, A.; Bhattacharyya, M.S.; Monduzzi, M.; Solinas, V. Role of the Support Surface on the Loading and the Activity of Pseudomonas Fluorescens Lipase Used for Biodiesel Synthesis. J. Mol. Catal. B Enzym. 2009, 57, 262-269. [CrossRef]

16. Kumari, V.; Shah, S.; Gupta, M.N. Preparation of Biodiesel by Lipase-Catalyzed Transesterification of High Free Fatty Acid Containing Oil from Madhuca Indica. Energy Fuels 2007, 2, 368-372. [CrossRef]

17. Hartmann, M.; Kostrov, X. Immobilization of Enzymes on Porous Silicas-Benefits and Challenges. Chem. Soc. Rev. 2013, 42, 6277-6289. [CrossRef] [PubMed]

18. Mateo, C.; Palomo, J.M.; Fuentes, M.; Betancor, L.; Grazu, V.; López-Gallego, F.; Pessela, B.C.C.; Hidalgo, A.; Fernández-Lorente, G.; Fernández-Lafuente, R.; et al. Glyoxyl Agarose: A Fully Inert and Hydrophilic Support for Immobilization and High Stabilization of Proteins. Enzym. Microb. Technol. 2006, 39, 274-280. [CrossRef]

19. Wang, X.; Qin, X.; Li, D.; Yang, B.; Wang, Y. One-Step Synthesis of High-Yield Biodiesel from Waste Cooking Oils by A Novel and Highly Methanol-Tolerant Immobilized Lipase. Bioresour. Technol. 2017, 235, 18-24. [CrossRef]

20. Amini, Z.; Ong, H.C.; Harrison, M.D.; Kusomo, F.; Mazaheri, H.; Ilham, Z. Biodiesel Production by Lipase-Catalyzed Transesterification of Ocimum basilicum L. (sweet basil) Seed Oil. Energy Convers. Manage. 2017, 132, 82-90. [CrossRef]

21. Nigam, S.; Mehrotra, S.; Vani, B.; Mehrotra, R. Lipase Immobilization Techniques for Biodiesel Roduction: An Overview. Int. J. Renew. Energy Biofuels 2014, 1-16.

22. Babaki, M.; Yousefi, M.; Habibi, Z.; Mohammadi, M. Process Optimization for Biodiesel Production from Waste Cooking Oil Using Multi-Enzyme Systems through Response Surface Methodology. Renew. Energy 2017, 105, 465-472. [CrossRef]

23. Gihaz, S.; Weiser, D.; Dror, A.; Satorhelyi, P.; Willemsen, M.J.; Poppe, L.; Fishman, A. Creating A Methanol -Stable Biocatalyst by Protein and Immobilization Engineering Steps Towards Efficient Biosynthesis of Biodiesel. ChemSusChem 2016, 9, 1-11. [CrossRef] [PubMed]

24. Amini, Z.; Ilham, Z.; Ong, H.C.; Mazaher, H.; Chen, W.-H. State of the Art and Prospective of Lipase-Catalyzed Transesterification. Energy Convers. Manage. 2017, 141, 339-353. [CrossRef]

25. Li, K.; Fan, Y.; He, Y.; Zeng, L.; Han, X.; Yan, Y. Burkholderia cepacia Lipase Immobilized on Heterofunctional Magnetic Nanoparticles and its Application in Biodiesel Synthesis. Sci. Rep. 2017, 7, 1647. [CrossRef] [PubMed]

26. Sharma, R.K.; Saxena, M.; O’Neill, C.A.; Ramos, H.A.R.; Greibenow, K. Synthesis of Rhizopus arrhizus Lipase Nanoparticles for Biodiesel Production. ACS Omega 2018, 3, 18203-18213. [CrossRef]

27. Pavlidis, I.V.; Vorhaben, T.; Tsoufis, T.; Rudolf, P.; Bornscheuer, U.T.; Gournis, D.; Stamatis, H. Development of Effective Nanobiocatalytic Systems through the Immobilization of Hydrolases on Functionalized Carbon-Based Nanomaterials. Bioresour. Technol. 2012, 115, 164-171. [CrossRef] 
28. Wang, L.; Liu, X.; Jiang, Y.; Zhou, L.; Ma, L.; He, Y.; Gao, J. Biocatalytic Pickering Emulsions Stabilized by Lipase-Immobilized Carbon Nanotubes for Biodiesel Production. Catalyst 2018, 8, 587. [CrossRef]

29. Farooqui, U.R.; Ahmad, A.L.; Hamid, N.A. A Promising Membrane Material for Fuel Cells. Renew. Sust. Energ. Rev. 2018, 82, 714-733. [CrossRef]

30. Zhang, J.; Zhang, F.; Yang, H.; Huang, X.; Liu, H.; Zhang, J.; Shouwu, G. Graphene Oxide as A Atrix for Enzyme Immobilization. Langmuir 2010, 26, 6083-6085. [CrossRef]

31. Qiu, Z.; Zhao, L.; Weatherley, L. Process Intensification Technologies in Continuous Biodiesel Production. Chem. Eng. Process. 2010, 49, 323-330. [CrossRef]

32. Poppe, J.K.; Fernandez-Lafuente, R.; Rodrigues, R.C.; Záchia Ayub, M.A. Enzymatic Reactors for Biodiesel Synthesis: Present Status and Future Prospects. Biotechnol. Adv. 2015, 33, 511-525. [CrossRef]

33. Tran, D.T.; Chen, C.L.; Chang, J.S. Immobilization of Burkholderia sp. Lipase on a Ferric Silica Nanocomposite for Biodiesel Production. J. Biotechnol. 2012, 158, 112-119. [CrossRef] [PubMed]

34. Kuepethkaew, S.; Sangkharak, K.; Benjakul, S.; Klomklao, S. Optimized Synthesis of Biodiesel Using Lipase from Pacific White Shrimp (Litopenaeus Vannamei) Hepatopancreas. Renew. Energy 2017, 104, 139-147. [CrossRef]

35. Fan, Y.; Wu, G.; Su, F.; Li, K.; Xu, L.; Han, X.; Yan, Y. Lipase Oriented-Immobilized on Dendrimer-Coated Magnetic Multi-Walled Carbon Nanotubes toward Catalyzing Biodiesel Production from Waste Vegetable Oil. Fuel 2016, 178, 172-178. [CrossRef]

36. Bencze, L.C.; Bartha-Vári, J.H.; Katona, G.; Toșa, M.I.; Paizs, C.; Irimie, F.D. Nanobioconjugates of Candida antarctica Lipase B and Single-Walled Carbon Nanotubes in Biodiesel Production. Bioresour. Technol. 2016, 200, 853-860. [CrossRef]

37. Soumanou, M.M.; Bornscheuer, U.T. Improvement in Lipase-Catalyzed Synthesis of Fatty Acid Methyl Esters from Sunflower oil. Enzyme Microb. Technol. 2003, 33, 97-103. [CrossRef]

38. Lima, L.N.; Oliveira, G.C.; Rojas, M.J.; Castro, H.F.; Da Ros, P.C.; Mendez, A.A.; Giordano, R.L.; Tardioli, P.W. Immobilization of Pseudomonas fluorescens Lipase on Hydrophobic Supports and Application in Biodiesel Synthesis by Transesterification of Vegetable Oils in Solvent-Free Systems. J. Ind. Microbiol. Biotechnol. 2015, 42, 523-535. [CrossRef]

39. Zhang, W.W.; Yang, X.L.; Jia, J.Q.; Wang, N.; Hu, C.L.; Yu, X.Q. Surfactant-Activated Magnetic Cross-Linked Enzyme Aggregates (magnetic CLEAs) of Thermomyces Lanuginosus Lipase for Biodiesel Production. J. Mol. Catal. B Enzym. 2015, 115, 83-89. [CrossRef]

40. Samukawa, T.; Kaieda, M.; Matsumoto, T.; Ban, K. Pretreatment of Immobilized Candida Antarctica Lipase for Biodiesel Fuel Production from Plant Oil. J. Biosci. Bioeng. 2000, 90, 180-183. [CrossRef]

41. Kaieda, M.; Samukawa, T.; Kondo, A.; Fukuda, H. Effect of Methanol and Water Contents on Production of Biodiesel Fuel from Plant Oil Catalyzed by Various Lipases in A Solvent-Free System. J. Biosci. Bioeng. 2001, 91, 12-15. [CrossRef]

42. Tan, T.; Nie, K.; Wang, F. Production of Biodiesel by Immobilized Candida sp. Lipase at High Water Content. Appl. Biochem. Biotechnol. 2006, 128, 109-116. [CrossRef]

43. Peigney, A.; Laurent, C.; Flahaut, E.; Bacsa, R.R.; Rousset, A. Specific Surface Area of Carbon Nanotubes and Bundles of Carbon Nanotubes. Carbon 2001, 39, 507-514. [CrossRef]

44. Nelson, L.A.; Foglia, T.A.; Marmer, W.N. Lipase-Catalyzed Production of Biodiesel. J. Am. Oil Chem. Soc. 1996, 73, 1191-1195. [CrossRef]

45. Budžaki, S.; Miljić, G.; Sundaram, S.; Tišma, M.; Hessel, V. Cost Analysis of Enzymatic Biodiesel Production in Small-Scaled Packed-Bed Reactors. Appl. Energy 2018, 210, 268-278. [CrossRef]

46. Bartha-Vári, J.H.; Bencze, L.C.; Bell, E.; Poppe, L.; Katona, G.; Irimie, F.D.; Paizs, C.; Toşa, M.I. Aminated Single-Walled Carbon Nanotubes as Carrier for Covalent Immobilization of Phenylalanine Ammonia-Lyase. Period. Polytech. Chem. Eng. 2017, 61, 59-66.

Sample Availability: Samples of the compounds are not available from the authors. 